\title{
Effects of Hydrogeographical Origin on Zootechnical Parameters of Wild Populations of Oreochromis niloticus (Linnaeus, 1758)
}

\section{T. Olivier Amoussou 1,2,3 , Aboubacar Toguyeni1,2, Ibrahim Imorou Toko4, Antoine Chikous, Mivice Bravo², Issaka Youssao Abdou Karim²}

${ }^{1}$ Research Unit in Aquaculture and Aquatic Biodiversity, Polytechnic University of Bobo-Dioulasso, BoboDioulasso 01, Burkina Faso

${ }^{2}$ Laboratory of Animal Sciences and Meat Technologies, Department of Animal Health and Production, University of Abomey-Calavi, Abomey-Calavi, Benin

${ }^{3}$ Centre International de Recherche-Développement sur l'élevage en zone Subhumide (CIRDES), Bobo-Dioulasso 01, Burkina Faso

${ }^{4}$ Research Unit in Aquaculture and Aquatic Ecotoxicology, Department of Animal Production, Faculty of Agronomy, University of Parakou, Parakou, Benin

${ }^{5}$ Laboratory of Hydrobiology and Aquaculture, Faculty of Agronomic Sciences, University of Abomey-Calavi, Abomey-Calavi, Benin

\begin{abstract}
The effect of geographical origin on the zootechnical parameters of tilapias is very poorly documented, unlike production systems and farming methods. In this study, the growth and survival characteristics of Oreochromis niloticus individuals were analyzed in relation with their waterway of origin, sex and age at experimental fishing. Durung the rearing, the duplicate groups were constituted keeping the 2 sexes (male $v s$ female) separately. Fingerlings were fed using a granulated commercial fish feed (35\% of proteins; $3 \mathrm{~mm}$ in diameter). Apart from chlorophyll «a», 3 phytoplankton and 5 zooplankton species were also available in the rearing tank. The body weight, total length, standard length, average weight gain, nutritive quotient and survival rate were similar $(\mathrm{p}>0.05)$ between lake Toho and Couffo river but weaker at these two waterways than Ouémé river $(\mathrm{p}<0.05)$. The ponderal and linear specific growth rates were significantly identical between lake Toho and Couffo river but more important $(\mathrm{p}<0.001)$ in these two waterways than Ouémé river. The majority of the individuals indicated an allometric growth $(b<3)$, which is less desirable in fish farming. In short, 2 populations were identified: the group constituted by Ouémé river and the one including lake Toho and Couffo river. It appears important to lead actions (selective breeding, crossbreeding) to improve the zootechnical performances of these local populations in order to promote their aquaculture.
\end{abstract}

Keywords: Benin, Oreochromis niloticus, chlorophyll, plankton, aquaculture

\section{Introduction}

Fisheries products play an important role in the human nutrition worldwide. Fish represents $16.6 \%$ of the animal proteins supplies to the world population and $6.5 \%$ of all consumed proteins [1]. In addition, this sector provides substantial incomes to an important portion of the world population [1]. However, in many regions of sub-Saharan Africa, fish consumption remains too weak. Furthermore, populations of these regions do not fully benefit from the increasing contributions that fisheries and aquaculture bring elsewhere in terms of sustainable food security and incomes [1]-[3]. This can be explained by several factors such as overfishing and pollution of rivers, destruction of natural habitats of fish, introduction of new species and climate change that may cause the decline or disappearance of several fish species [4]-[6].

In this situation, fish-farming promotion becomes a necessity. For this purpose, tilapia species constitute, since decades, the main species for commercial fish

This article is published under the terms of the Creative Commons Attribution License 4.0

Author(s) retain the copyright of this article. Publication rights with Alkhaer Publications.

Published at: http://www.ijsciences.com/pub/issue/2017-05/

DOI: 10.18483/ijSci.1269; Online ISSN: 2305-3925; Print ISSN: 2410-4477 
farming in Africa [7], [8]. In 2012, aquaculture production in Africa reached 1,485,367 tonnes, which represents $2.23 \%$ of the world total production [1], with on average $20 \%$ for tilapia farming [9]. In fact, tilapia farming becomes the type of aquaculture the most practiced in Africa [1], [10]. The subfamily of tilapias belongs to the Cichlidae family and includes about 100 species grouped into three genera (Oreochromis, Sarotherodon and Tilapia) which differentiate themselves by their reproductive behavior and diet [11], [12]. The main types used in aquaculture are Oreochromis and Sarotherodon including four species that are now farmed on a significant scale: Oreochromis niloticus, Sarotherodon melanotheron, Oreochromis aureus, Oreochromis mossambicus and their hybrids [7], [13]-[16]. In the developing world, Tilapia production is rising with a new offer that targets national and regional consumers rather than international markets [1]. It now represents the major source of income of African fish farmers [17], [18]. Their production is expected to be higher than 9.2 million tonnes in 2030 [1].

The Tilapiini have been divided into 10 genera based on breeding habit, food and trophic adaptations, structural characters and biogeography [19]. In Oreochromis niloticus, the effect of geographical origin is most often tested on levels of microbial infection and metal contamination but rarely on zootechnical parameters. A molecular technique using $16 \mathrm{~S}$ rDNA profiles generated by PCR-DGGE was used in order to detect the variation in bacterial community structures of Oreochromis niloticus from three different lakes of the north of Cameroon and the effect of the season and fish species on these bacteria profiles [20]. It emerges that the fish species did not have an influence on microbial profiles of fish contrarily to the season. However, Streptococcus agalactiae, a major pathogen of Nile tilapia in Brazil, exhibited high virulence, regardless of the geographic origin of the isolated strains [21]. Furthermore, the international transport of fish contributes to the rapid movement of viral strains across regions [22]. Moreover, higher levels of chromium, nickel, silver, arsenic, zinc, copper and, at a lesser extent, cadmium and selenium were observed in selected fish and invertebrate species from Mugu Lagoon, Malibu Lagoon and Ballona Wetlands in southern California [23]. The aim of this study was to evaluate the biological, growth, survival and reproductive parameters of Oreochromis niloticus (Linnaeus, 1758) in relation with their waterways of origin, sex and ages at control harvesting for a better management of local resources to be used in selective breeding programs.

\section{Material and methods \\ Origin of sample}

In Benin, four major sets of basin were identified: the Niger river basin, the Volta river basin, the coastal watershed which includes Mono-Couffo on the Western side and Ouémé-Yéwa set on the Eastern side. The whole coastal complex flows into a lagoon system that connects the two West and East complexes. All fishes used in this study were from hydrographic areas of southern Benin (Table 1) under two agro-ecological context (subequatorial climate for Mono and Couffo basins and equatorial climate for Ouémé basin). The aquatic vegetation was scarce in Agonlinlowé (Ouémé river), Logbo and Lanta (lake Toho) while it was abundant in the six other sampling sites.

Table 1: Location of sampling sites based on the hydrographic basins of Southern Benin.

\begin{tabular}{|c|c|c|c|c|}
\hline \multirow{2}{*}{ Sub-river basin } & \multirow{2}{*}{ Zone } & \multirow{2}{*}{ Site } & \multicolumn{2}{|c|}{ GPS Co-ordinates } \\
\hline & & & Latitude & Longitude \\
\hline \multirow{3}{*}{ Couffo } & \multirow{3}{*}{ Couffo river } & Lanta & $07^{\circ} 06^{\prime} 43.6^{\prime \prime} \mathrm{N}$ & $001^{\circ} 52^{\prime} 44.3^{\prime \prime} \mathrm{E}$ \\
\hline & & Sahouamè & $07^{\circ} 07^{\prime} 09.0^{\prime \prime} \mathrm{N}$ & $001^{\circ} 52^{\prime} 14.6^{\prime \prime} \mathrm{E}$ \\
\hline & & Tohou & $07^{\circ} 05^{\prime} 54.4^{\prime \prime} \mathrm{N}$ & $001^{\circ} 52^{\prime} 46.6^{\prime \prime} \mathrm{E}$ \\
\hline \multirow{3}{*}{ Mono } & \multirow{3}{*}{ Lake Toho } & Logbo & $06^{\circ} 37^{\prime} 02.6^{\prime \prime} \mathrm{N}$ & $001^{\circ} 46^{\prime} 03.5^{\prime \prime} \mathrm{E}$ \\
\hline & & Douimè & $06^{\circ} 37^{\prime} 33.1^{\prime \prime} \mathrm{N}$ & $001^{\circ} 46^{\prime} 59.0^{\prime \prime} \mathrm{E}$ \\
\hline & & Kpinnou & $06^{\circ} 36^{\prime} 36.3^{\prime \prime} \mathrm{N}$ & $001^{\circ} 46^{\prime} 21.8^{\prime \prime} \mathrm{E}$ \\
\hline \multirow{3}{*}{ Ouémé } & \multirow{3}{*}{ Ouémé river } & Agonlinlowé & $06^{\circ} 39^{\prime} 54.0^{\prime \prime} \mathrm{N}$ & $002^{\circ} 28^{\prime} 57.0^{\prime \prime} \mathrm{E}$ \\
\hline & & Hêtin-Sota & $06^{\circ} 35^{\prime} 41.6^{\prime \prime} \mathrm{N}$ & $002^{\circ} 30^{\prime} 16.9^{\prime \prime} \mathrm{E}$ \\
\hline & & Avagbodji & $06^{\circ} 31^{\prime} 30.3^{\prime \prime} \mathrm{N}$ & $002^{\circ} 31^{\prime} 55.7^{\prime \prime} \mathrm{E}$ \\
\hline
\end{tabular}

\section{Experimental procedure}

The experiment was carried out at the fish farming station of the Department of Animal Health and Production of the University of Abomey-Calavi, Benin. It was conducted in 4 identical tanks of immersed volume $4 \mathrm{~m}^{3}(2 \mathrm{~m} \times 2 \mathrm{~m} \times 1 \mathrm{~m})$, each containing manual-sexed individuals. Fishing net of $10 \mathrm{~mm}$ mesh size was used as hapas and allowed to keep individuals from the three waterways (Ouémé river, lake Toho and Couffo river) separately. So there were three compartments in each tank (block). Each block was duplicated such as the blocks 1 and 2 
were for males and blocks 3 and 4 for females. The stocking density of each batch was 20 individuals $\mathrm{m}^{-}$ 3 . The fish used in the experiment were Oreochromis niloticus' fry with an average weight equal to $21.27 \pm$ $11.57 \mathrm{~g}$ and descended from the first mating generation between wild broodfish. Fry were on average aged of 3 months 15 days and tagged individually.

For feeding and controls, during fry rearing and fingerlings breeding, fish were fed with commercial feed (Skretting ${ }^{\circledR}$ ): diameter $1 \mathrm{~mm}$ (containing $57 \%$ of proteins) and diameter $3 \mathrm{~mm}$ (containing $35 \%$ of proteins) respectively. Fish of every block were fed manually three times per day: at 8 a.m., 12 p.m. and 5 p.m. The ratio of $5 \%$ of the biomass was applied during the experiment for feeding as in [24]. Controls of weight gain and survival were done every 15 days on $10 \%$ and $100 \%$ of the population in breeding respectively during the nursery and during the post nursery period.

\section{Water quality assessment}

The physicochemical parameters such as conductivity $\left(\mu \mathrm{S} \mathrm{cm}^{-1}\right), \mathrm{pH}$, dissolved oxygen $\left(\mathrm{mg} \mathrm{L}^{-1}\right)$, temperature $\left({ }^{\circ} \mathrm{C}\right)$, salinity $\left(\mathrm{mg} \mathrm{L}^{-1}\right)$ and $\mathrm{TDS}(\mathrm{ppm})$ were recorded twice per day (at 7:00 a.m. and at 5:00 p.m.). The microalgal biomass and plankton abundance were determined as described in [25].

\section{Data calculation}

The feed intake, growth and survival parameters were calculated using Microsoft Excel 2010. The Weight gain (WG) was determined by subtracting initial weight from final weight. Average weight gain was determined using the formula: AWG = final mean weight/final number of fish; daily weight gain as DWG $\left(\mathrm{g} \mathrm{day}^{-1}\right)=\mathrm{AWG}^{*}$ breeding period ${ }^{-1}$; ponderal specific growth rate as PSGR $\left(\%\right.$ day $\left.^{-1}\right)=$ $100^{*}[\ln (($ final mean fish weight)- $\ln$ (initial mean fish weight $))^{*}$ breeding period $\left.^{-1}\right]$; linear specific growth rate as LSGR $\left(\%\right.$ day $\left.^{-1}\right)=100 *[\ln (($ final mean fish total length)-ln(initial mean fish total length))*breeding period ${ }^{-1}$ ]; nutritive quotient as NQ = quantity of dry food distributed*weight gain $^{-1}$; and survival rate as $\mathrm{SR}=100 *$ (final number of fish*initial number of fish ${ }^{-1}$ ). Net biomass (NB) was determined by subtracting initial biomass from final biomass. Biomass per square meter was determined using the formula: BPM $\left(\mathrm{g} \mathrm{m}^{-2}\right)=$ net biomass* surface area ${ }^{-1}$.

The Total length-Weight relationship was described by the power type equation $\mathrm{BW}=\mathrm{aTL} \mathrm{L}^{\mathrm{b}}$, Where: $\mathrm{BW}=$ body weight $(\mathrm{g}), \mathrm{TL}=$ total length $(\mathrm{cm}), \mathrm{a}=$ fish's environment coefficient and $b=$ logarithmic slope or relative growth coefficient. The condition factor was calculated using the equation: $\mathrm{K}=100 \mathrm{BW} * \mathrm{SL}^{-3}$, Where: $\mathrm{K}=$ relative condition factor; $\mathrm{BW}=$ body weight $(\mathrm{g}) ; \mathrm{TL}=$ total length (TL $\mathrm{cm}) ; \mathrm{SL}=$ standard length (SL cm).

The maturity stages of gonads were determined by macroscopic analysis based on the 5 scales of gonadal maturation [26]. Gonado-Somatic Ratio (GSR) and Gonado-Somatic Index (GSI) correspond respectively to the gonad weight $(\mathrm{GW})$ in percentage of the body weight $(\mathrm{BW})\left(\mathrm{GSR}=\mathrm{GW} / \mathrm{BW}^{*} 100\right)$ and the eviscerated fish weight (EW) (GSI=GW/EW*100). The formula used to calculate the gonad weight-fish size ratio was $\mathrm{R}=\mathrm{GW} / \mathrm{TL}^{3} * 10^{3}$. Where $\mathrm{GW}=$ gonad weight $(\mathrm{g})$; $\mathrm{BW}=$ body weight; $\mathrm{EW}=$ eviscerated fish weight $(\mathrm{g}), \mathrm{TL}=$ fish's total length $(\mathrm{cm})$.

\section{Statistical analysis}

The linear model procedure of $\mathrm{R}$ software (http://cran.r-project.org) was used for data analysis. The dual effect of the waterway of origin and age at experimental fishing and, the simultaneous effect of the sex and age at experimental fishing were tested. Interactions were not significant and thus, the three factors (waterway, sex and age at experimental fishing) are not influenced by their interactions. The mathematical expression of the model without interaction obtained was:

Where:

$$
\mathrm{Y}_{\mathrm{ijkl}}=\mu+\mathrm{W}_{\mathrm{i}}+\mathrm{S}_{\mathrm{j}}+\mathrm{Age}_{\mathrm{k}}+\text { eijkl }
$$

$\mathrm{Y}_{\mathrm{ijk} \mathrm{l}}$ : zootechnical performance of individual 1, from $\mathrm{i}^{\text {th }}$ waterway, of the $\mathrm{j}^{\text {th }}$ sex and of the $\mathrm{k}^{\text {th }}$ age at experimental fishing;

$\mu$ : grand mean effect;

$\mathrm{W}_{\mathrm{i}}$ : differential effect of the $\mathrm{i}^{\text {th }}$ waterway (Ouémé river, lake Toho and Couffo river);

$S_{j}$ : differential effect of the $j^{\text {th }}$ sex (male and female); Age $_{\mathrm{k}}$ : differential effect of the $\mathrm{k}^{\text {th }}$ age at experimental fishing (30, 60 and 90 DPN);

eijkl: residual effect of the zootechnical performance of the 1 individual, from the $i^{\text {th }}$ waterway, of the $j^{\text {th }}$ sex and of the $\mathrm{k}^{\text {th }}$ age at experimental fishing.

The $\mathrm{F}$ test was used to determine the significance of each effect and means were compared pairwise using the $\mathrm{t}$ test of Student. The Principal Components Analysis (PCA) was computed by the $P C A$ procedure of $\mathrm{R}$. The hclust method of $\mathrm{R}$ was used to achieve the dendrogram.

\section{Results \\ Biological quality of the rearing water}

The strongest production of chlorophyll «a» was observed in tank number 3 while its lowest value was recorded in tank 4 (Figure 1). Similarly, the production of chlorophyll « $\mathbf{a}$ » was significantly more important $(\mathrm{p}<0.05)$ in tanks 2 and 3 than in the 
breeding tanks 1 and 4 . A total of 3 phytoplankton species (Scenedesmus quadricauda, Euglena oxyuris, Aulacoseira granulata) against 5 zooplankton species (Lecane bulla, Lepadella ovalis, Trichocerca sp, Polyarthra vulgaris, Elaphoidella grandidieri) were numbered. Elaphoidella grandidieri was seen both as nauplii of copepod and harpacticoid copepod. The tank 3 was the richest in phytoplankton species $\left(60,240\right.$ individuals $\left.L^{-1}\right)$, while the less rich one was the number $1\left(17,866\right.$ individuals $\left.\mathrm{L}^{-1}\right)$. With regard to zooplankton species, tanks number 2 and 3 were respectively the most (643 individuals $\mathrm{L}^{-1}$ ) and the less (87 individuals $\mathrm{L}^{-1}$ ) abounded (Figure 2).

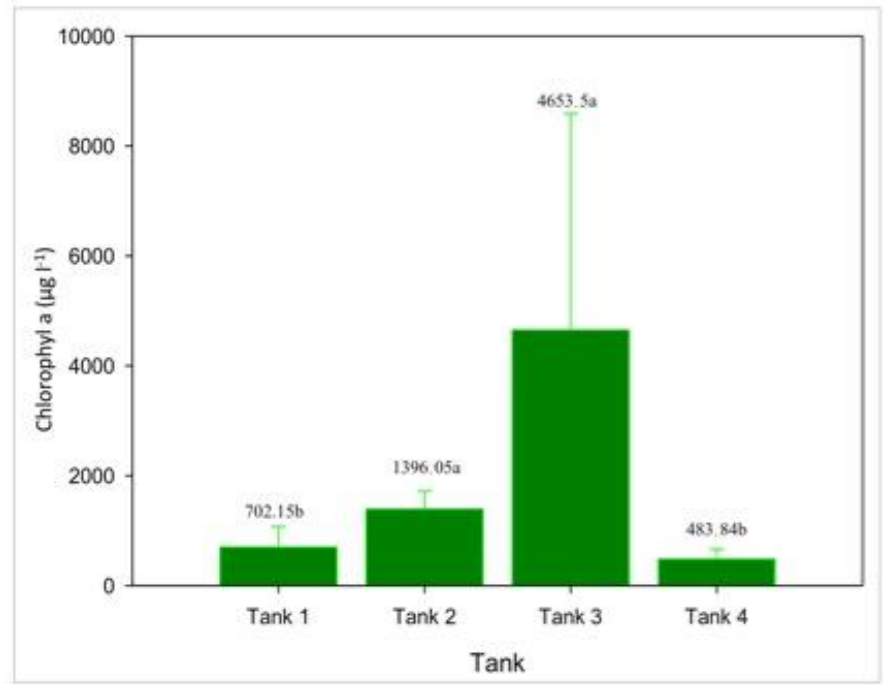

Figure 1: Concentration in chlorophyll «a» in each rearing tank. From a tank to another, the means with different alphabetic superscripts are different at the threshold of $5 \%$.

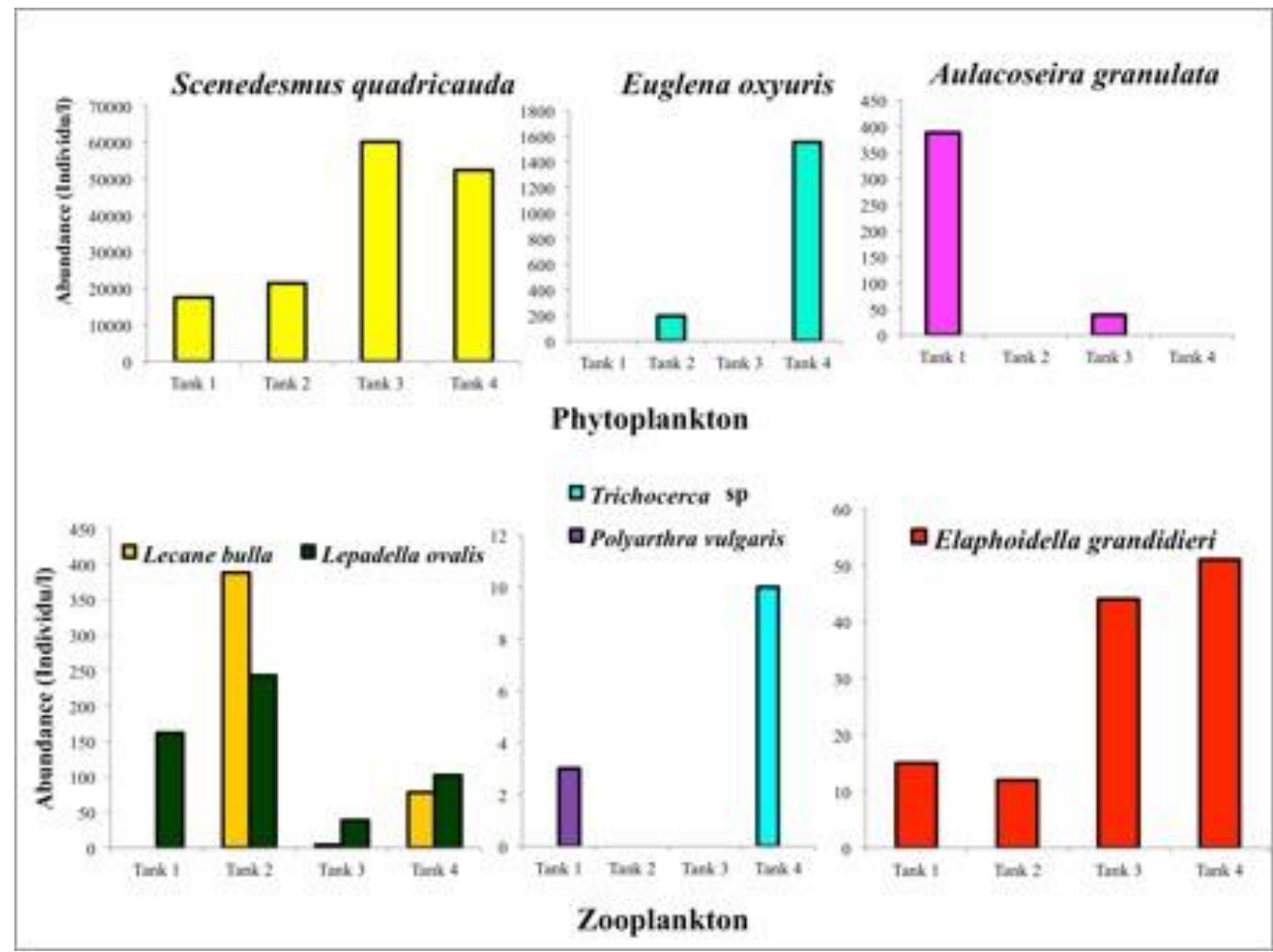

Figure 2: Diversity and abundance of planktons. Each color corresponds to a plankton species. 
Physicochemical quality of the rearing water Whether in morning or evening, the physicochemical parameters such as $\mathrm{pH}$, dissolved oxygen, salinity and TDS did not vary significantly according to a rearing tank (Figure 3). The water conductivity followed the same tendency except for mornings of the first 30 DPN. Indeed, in this period, it was significantly lower $(p<0.05)$ in tanks 2 and 3 than in tanks 1 and 4. Similarly, it was, not only, similar between tanks 2 and 3 but also, between tanks 1 and 4. In the evening, the water temperature was identical ( $p>0.05)$ from a breeding tank to another whatever the rearing period. In morning, the same tendency was observed during the first 60 DPN. During the last 30 days of rearing, in the tank 3 , the temperature was intermediate $(\mathrm{p}<0.01)$ between tanks 1,2 and 4 . It was higher in tanks 1 and 2 than in tank number 4 $(\mathrm{p}<0.05)$.

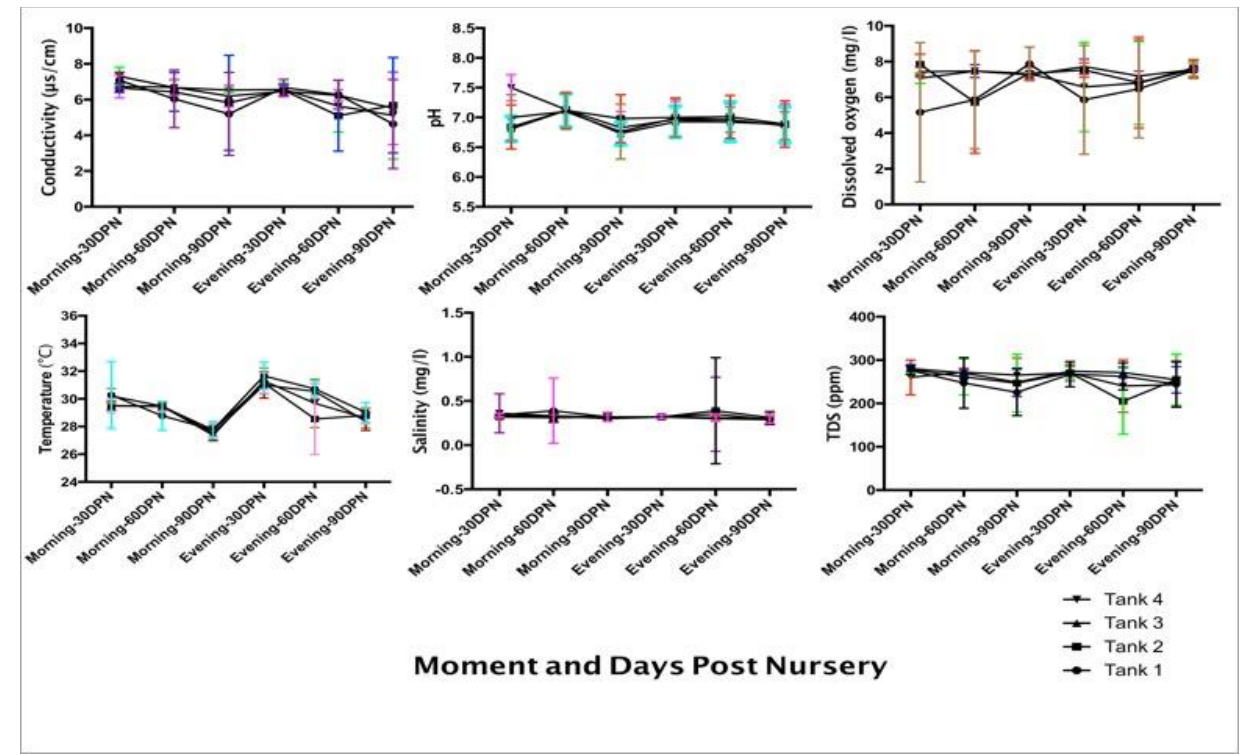

Figure 3: Variation of physicochemical parameters according to the time of the day and period post nursery. DPN: Days Post Nursery.

\section{Effects of the waterway, sex and age at experimental harvesting}

The weight gain, daily weight gain, condition factor, net biomass and biomass per square meter did not vary significantly from a waterway to another ( $p>0.05)$. However, the body weight, total length, standard length, average weight gain, nutritive quotient and survival rate were similar $(\mathrm{p}>0.05)$ between lake Toho and Couffo river but weaker at these two waterways than Ouémé river $(p<0.05)$. The ponderal and linear specific growth rates were significantly identical between lake Toho and Couffo river but more important in these two waterways than in Ouémé river $(\mathrm{p}<0.001)$. Apart from the body weight which was significantly higher in males than females $(51.54 \pm 25.16$ vs $40.32 \pm 20.41$, $\mathrm{p}<0.05)$, all the others zootechnical parameters did not vary significantly according to the sex $(p>0.05)$. The average weight gain and nutritive quotient did not vary significantly $(\mathrm{p}>0.05)$ according to the DPN. However, the body weight, weight gain, daily weight gain, net biomass and biomass per square meter were significantly higher during the last 30 days of rearing than during the first 60 DPN $(p<0.001)$. The total length, standard length, ponderal specific growth rate and linear specific growth rate were not only, weaker during the first 30 DPN than during the last 60 days of rearing and but also, weaker during 60 DPN than during the last $30 \mathrm{DPN}(\mathrm{p}<0.01)$. As for the condition factor, it followed the opposite tendency. The survival rate was more important during the first 30 days of rearing than during the last 30 days of rearing $(\mathrm{p}<0.05)$. During the $60 \mathrm{DPN}$, this parameter was intermediate $(p>0.05)$ between the first 30 days and the last 30 DPN (Table 2).

\section{Multivariate analysis}

Principal Components Analysis (PCA) and dendrogram applied on zootechnical characteristics of Oreochromis niloticus stood out 2 groups: the group that is only constituted of Ouémé river and the one including lake Toho with Couffo river (Figures 4 \& 5). Oreochromis niloticus individuals from Couffo river and Lake Toho were characterized by weaker ponderal and linear specific growth rates while Ouémé river' individuals were characterized by higher body weight, total length, standard length, weight gain, average weight gain, daily weight gain, nutritive quotient, survival rate, net biomass and biomass per square meter (Figure 4). 


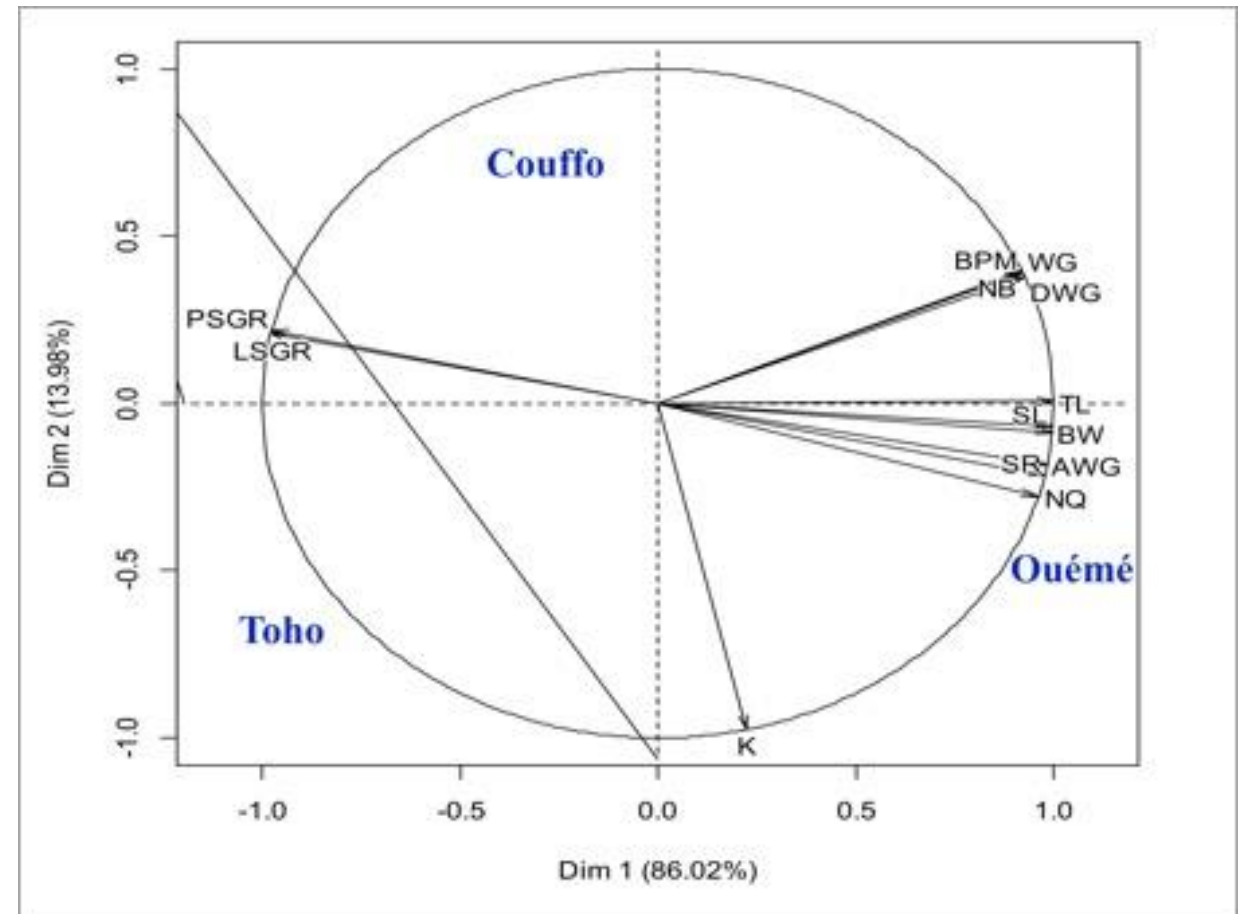

Figure 4: PCA analysis based on the zootechnical parameters. BW: Body Weight; TL: Total Length; SL: Standard Length; WG: Weight Gain; AWG: Average Weight Gain; DWG: Daily Weight Gain; PSGR: Ponderal Specific Growth Rate; LSGR: Linear Specific growth rate; NQ: Nutritive Quotient; K: Condition factor; SR: Survival Rate; NB: Net Biomass; BPM: Biomass per square meter.

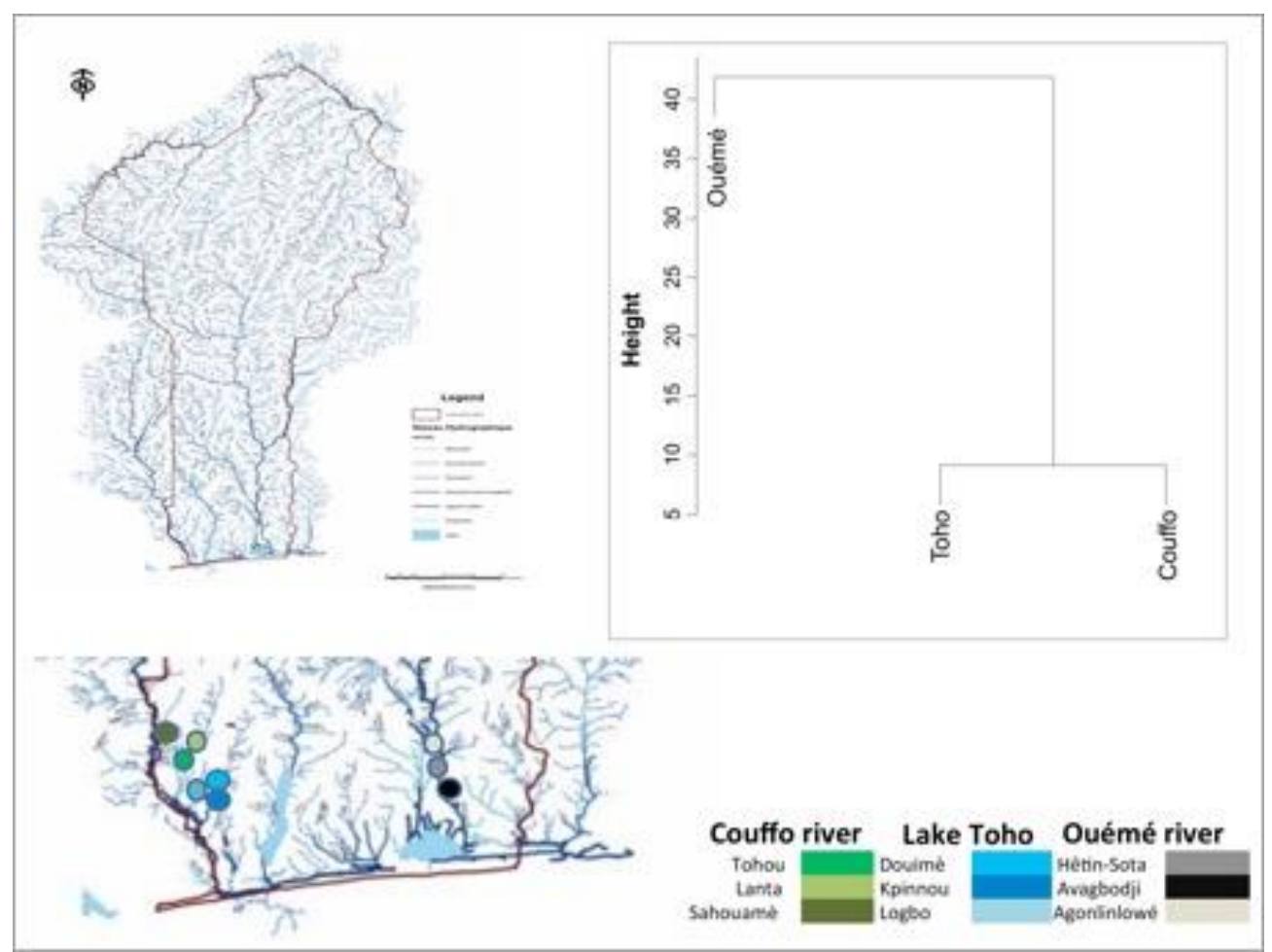

Figure 5: Geographical location and proximity of Oreochromis niloticus's populations. Each color in the map corresponds to a sampling site. 
Relative growth and reproductive characteristics Equations of Total length-Weight relationships showed that, overall, the body weight was strongly correlated with the total length $\left(0.74 \leq R^{2} \leq 0.99\right)$. The relative growth coefficient (b) varied from 2.38 to 3.22. Globally, females had their b values superior to those of males (Table 3). After rearing, the gonadosomatic parameters were globally more elevated among females than males. Indeed, in males, the gonads weight, gonado-somatic ratio, gonadosomatic index and gonad weight-fish size ratio varied respectively from $0.21 \pm 0.2 \mathrm{~g}$ to $0.23 \pm 0.2 \mathrm{~g}, 0.20 \pm$ 0.15 to $0.27 \pm 0.19,0.23 \pm 0.17$ to $0.31 \pm 0.23$ and $0.07 \pm 0.06$ to $0.10 \pm 0.07$. Moreover, among females, these parameters remained respectively within the ranges of $1.41 \pm 0.78 \mathrm{~g}$ to $2.03 \pm 1.93 \mathrm{~g}$, $1.86 \pm 1.51$ to $2.59 \pm 1.17,0.67 \pm 0.55$ to $2.93 \pm 1.33$ and $0.67 \pm 0.55$ to $1.01 \pm 0.46$ (Figure 6). Furthermore, the majority of individuals were at maturity stage IV with percentages ranging from $42.86 \%$ to $93.33 \%$ (Figure 7).

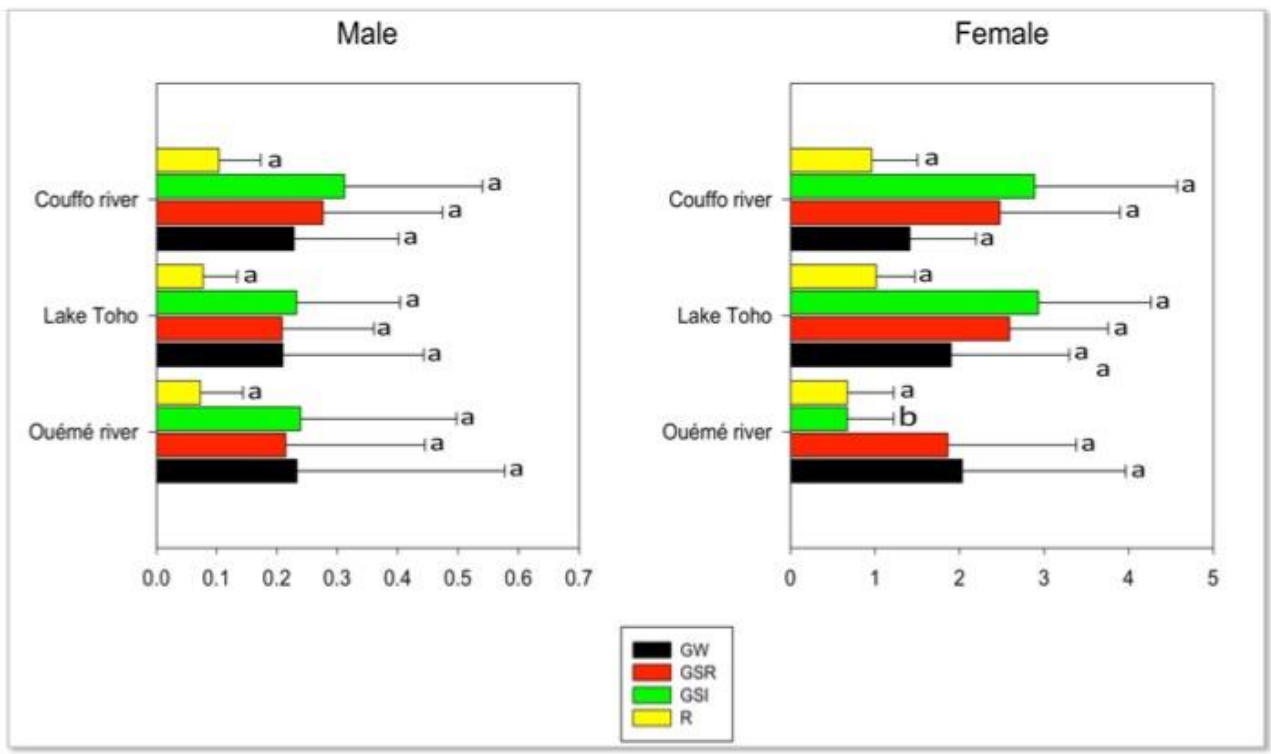

Figure 6: Gonado-somatic ratio, gonado-somatic index and gonad weight-fish size ratio of Oreochromis niloticus' individuals at the end of the experiment (GW: gonad weight; RGS: gonado-somatic ratio; GSI: gonado-somatic index; R: gonad weight-fish size ratio). For each sex, the means of the same reproductive parameter with different alphabetic superscripts are different at the threshold of $5 \%$.

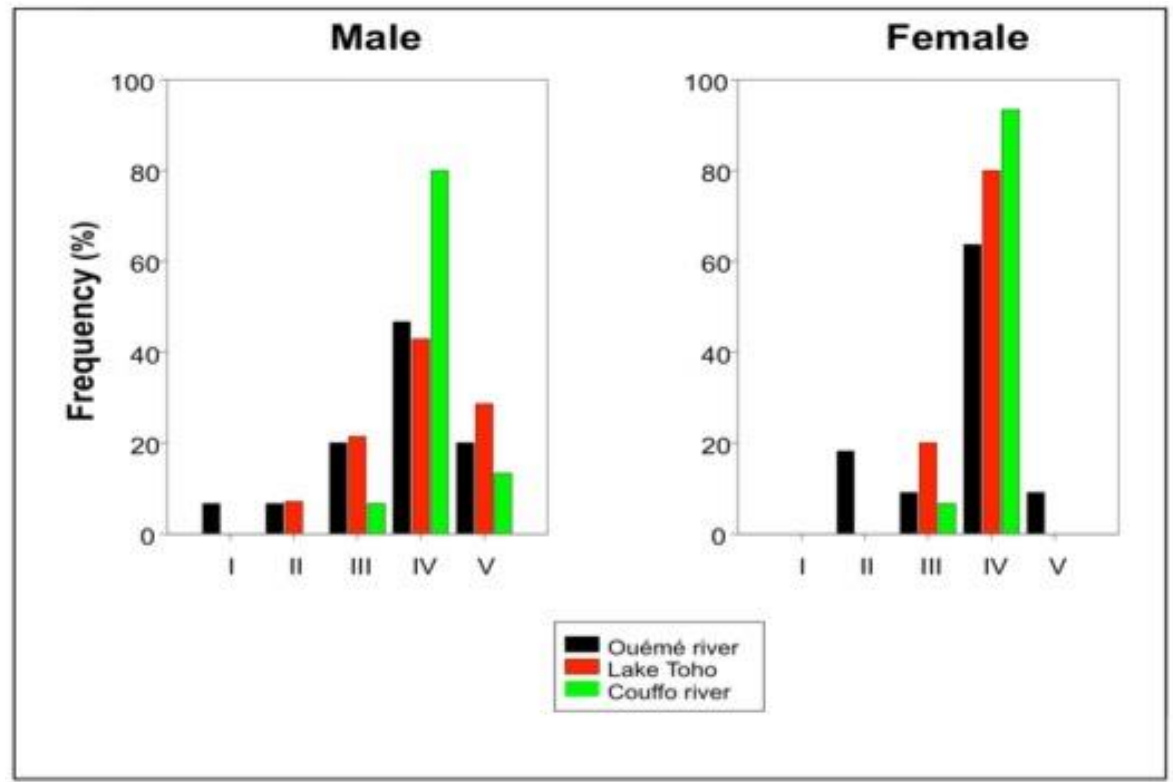

Figure 7: Stage of sexual maturity of Oreochromis niloticus' individuals at the end of the experiment. I = stage 1; II $=$ stage $2 ; \mathrm{III}=$ stage $3 ; \mathrm{IV}=$ stage $4 ; \mathrm{V}=$ stage 5 . 
Effects of Hydrogeographical Origin on Zootechnical Parameters of Wild Populations of Oreochromis niloticus (Linnaeus, 1758)

Table 2: Variation of zootechnical parameters per waterway, sex and age at experimental fishing.

\begin{tabular}{|c|c|c|c|c|c|c|c|c|c|c|c|c|c|c|c|c|c|c|c|}
\hline \multirow{3}{*}{ Variable } & \multicolumn{6}{|c|}{ Waterwax } & \multicolumn{4}{|c|}{ Sex } & \multicolumn{6}{|c|}{ Age at control fishing } & \multicolumn{3}{|c|}{ Significativity } \\
\hline & \multicolumn{2}{|c|}{ Ouémé river } & \multicolumn{2}{|c|}{ Lake Toho } & \multicolumn{2}{|c|}{ Couffo river } & \multicolumn{2}{|c|}{ Male } & \multicolumn{2}{|c|}{ Female } & \multicolumn{2}{|c|}{$30 \mathrm{DPN}$} & \multicolumn{2}{|c|}{60 DPN } & \multicolumn{2}{|c|}{$90 \mathrm{DPN}$} & \multirow{2}{*}{ Waterway } & \multirow{2}{*}{ Sex } & \multirow{2}{*}{ Age } \\
\hline & M & SD & M & SD & M & SD & M & SD & M & SD & M & SD & M & SD & M & SD & & & \\
\hline BW (g) & $64.45 a$ & 22.7 & $34.14 \mathrm{~b}$ & 17.7 & $39.22 \mathrm{~b}$ & 17.88 & $51.54 \mathrm{a}$ & 25.16 & $40.32 \mathrm{~b}$ & 20.41 & $42.67 \mathrm{~b}$ & 27.5 & $49.99 \mathrm{~b}$ & 12.5 & $66.78 \mathrm{a}$ & 15.7 & **** & * & $* * *$ \\
\hline TL $(\mathrm{cm})$ & $14.15 \mathrm{a}$ & 1.68 & $11.35 \mathrm{~b}$ & 2.18 & $12.07 \mathrm{~b}$ & 2.15 & $12.86 \mathrm{a}$ & 2.26 & $1219 \mathrm{a}$ & 2.35 & $11.75 \mathrm{c}$ & 1.38 & $13.37 \mathrm{~b}$ & 1.16 & $14.96 \mathrm{a}$ & 1.3 & **** & NS & *** \\
\hline $\mathrm{SL}(\mathrm{cm})$ & $12.05 \mathrm{a}$ & 3.18 & $8.87 \mathrm{~b}$ & 1.82 & $9.46 \mathrm{~b}$ & 1.79 & $10.71 \mathrm{a}$ & 3.23 & $9.55 \mathrm{a}$ & 1.92 & $9.31 \mathrm{c}$ & 1.72 & $10.53 \mathrm{~b}$ & 0.97 & $11.86 \mathrm{a}$ & 1.06 & **** & NS & ** \\
\hline WG (g) & $32.74 \mathrm{a}$ & 17.71 & $24.65 \mathrm{a}$ & 12.86 & $29.55 \mathrm{a}$ & 14.05 & $32.27 \mathrm{a}$ & 15.69 & $25.68 \mathrm{a}$ & 13.85 & $18.36 \mathrm{~b}$ & 17.6 & $26.09 \mathrm{~b}$ & 4.74 & $42.48 \mathrm{a}$ & 7.09 & NS & NS & $* * *$ \\
\hline AWG (g) & $9.09 \mathrm{a}$ & 2.77 & $2.58 \mathrm{~b}$ & 1.1 & $3.01 \mathrm{~b}$ & 1.16 & $5.22 \mathrm{a}$ & 3.79 & $4.57 \mathrm{a}$ & 3.28 & $3.93 \mathrm{a}$ & 4.02 & $4.49 \mathrm{a}$ & 2.66 & $6.26 \mathrm{a}$ & 3.56 & $* * *$ & NS & NS \\
\hline DWG $\left(\right.$ g.day $\left.^{-1}\right)$ & $1.09 \mathrm{a}$ & 0.59 & $0.82 \mathrm{a}$ & 0.43 & $0.98 \mathrm{a}$ & 0.47 & $1.08 \mathrm{a}$ & 0.52 & $0.86 \mathrm{a}$ & 0.46 & $0.61 \mathrm{~b}$ & 0.59 & $0.87 \mathrm{~b}$ & 0.16 & $1.42 \mathrm{a}$ & 0.23 & NS & NS & *** \\
\hline PSGR $\left(\%\right.$.day $\left.{ }^{-1}\right)$ & $1.91 \mathrm{~b}$ & 0.81 & $3.2 \mathrm{a}$ & 1.25 & $3.17 \mathrm{a}$ & 1.03 & $2.92 \mathrm{a}$ & 1.12 & $2.8 \mathrm{a}$ & 1.28 & $1.83 \mathrm{c}$ & 0.69 & $2.76 \mathrm{~b}$ & 1.02 & $3.7 \mathbf{a}$ & 1.03 & $* * *$ & NS & $* * *$ \\
\hline LSGR $\left(\% \cdot\right.$ day $\left.^{-1}\right)$ & $0.63 \mathrm{~b}$ & 0.31 & $1.17 \mathbf{a}$ & 0.39 & $1.15 \mathrm{a}$ & 0.38 & $1.97 \mathbf{a}$ & 0.43 & $1 \mathrm{a}$ & 0.45 & $0.56 \mathrm{c}$ & 0.2 & $1.02 \mathrm{~b}$ & 0.31 & $1.37 \mathrm{a}$ & 0.31 & $* * *$ & NS & $* * *$ \\
\hline NQ & $3.48 \mathrm{a}$ & 2.1 & $1.79 \mathrm{~b}$ & 0.66 & $1.71 \mathrm{~b}$ & 0.3 & $2.38 \mathrm{a}$ & 1.61 & $2.28 \mathrm{a}$ & 1.42 & $2.6 \mathrm{a}$ & 1.71 & $2.58 \mathrm{a}$ & 1.89 & $1.79 \mathrm{a}$ & 0.42 & $* *$ & NS & NS \\
\hline $\mathrm{K}$ & $3.85 \mathrm{a}$ & 1.44 & $3.86 \mathrm{a}$ & 1.01 & $3.7 \mathbf{a}$ & 0.93 & $3.93 \mathrm{a}$ & 1.29 & $3.67 \mathrm{a}$ & 0.94 & $4.87 \mathrm{a}$ & 1.1 & $4.17 \mathrm{~b}$ & 0.2 & $3.94 \mathrm{c}$ & 0.17 & NS & NS & *** \\
\hline SR (\%) & $95.11 \mathrm{a}$ & 10.23 & $82.73 \mathrm{~b}$ & 13.97 & $83.1 \mathrm{~b}$ & 11.67 & $85.15 \mathrm{a}$ & 15 & $88.81 \mathrm{a}$ & 10.94 & $93.72 \mathrm{a}$ & 10.2 & $87.82 \mathrm{ab}$ & 12.4 & $79.4 \mathrm{~b}$ & 13.1 & * & NS & * \\
\hline NB (g) & $32.74 a$ & 17.71 & $24.65 \mathrm{a}$ & 12.86 & $29.55 \mathrm{a}$ & 14.05 & $32.27 \mathrm{a}$ & 15.69 & $25.68 \mathrm{a}$ & 13.85 & $18.36 \mathrm{~b}$ & 17.6 & $26.09 \mathrm{~b}$ & 4.74 & $42.48 \mathrm{a}$ & 7.09 & NS & NS & *** \\
\hline $\mathrm{BPM}\left({\left.\mathrm{g} \cdot \mathrm{m}^{-2}\right)}^{-2}\right.$ & $8.18 \mathrm{a}$ & 4.43 & $6.16 \mathrm{a}$ & 3.21 & $7.39 \mathrm{a}$ & 3.51 & $8.07 a$ & 3.92 & $6.42 \mathrm{a}$ & 3.46 & $4.59 \mathrm{~b}$ & 4.4 & $6.52 \mathrm{~b}$ & 1.19 & $10.62 \mathrm{a}$ & 1.77 & NS & NS & $* * *$ \\
\hline
\end{tabular}

$* * *=\mathrm{p}<0.001 ; * *=\mathrm{p}<0.01 ; *=\mathrm{p}<0.05 ; \mathrm{NS}=\mathrm{p}>0.05 ; \mathrm{M}$ : Mean; $\mathrm{SD}:$ Standard Deviation; DPN: Days Post Nursery;

The intra-class means of the same row followed by the same letters don't differ significantly at the threshold of 5\%; BW: Body Weight; TL: Total Length; SL: Standard Length; WG: Weight Gain; AWG: Average Weight Gain; DWG: Daily Weight Gain; PSGR: Ponderal Specific Growth Rate; LSGR: Linear Specific growth rate; NQ: Nutritive Quotient; K: Condition factor; SR: Survival Rate; NB: Net Biomass; BPM: Biomass per square meter.

Table 3: Parameters of Oreochromis niloticus' weight-length relationships.

\begin{tabular}{|c|c|c|c|c|c|c|c|}
\hline Waterway & Ratio & Sex & b & $\mathbf{a}$ & $\mathbf{R}^{2}$ & Number & Logarithmic equations \\
\hline \multirow{12}{*}{ Ouémé river } & \multirow{3}{*}{$\mathrm{BW} / \mathrm{TL}$} & $\mathrm{M}+\mathrm{F}$ & 2.8 & 0.03 & 0.97 & 26 & $\operatorname{LogBW}=2.8 \log T L-1.52$ \\
\hline & & $\mathrm{M}$ & 2.74 & 0.04 & 0.96 & 15 & $\log B W=2.74 \log T L-1.40$ \\
\hline & & $\mathrm{F}$ & 2.9 & 0.02 & 0.98 & 11 & $\operatorname{LogBW}=2.9 \log T L-1.70$ \\
\hline & \multirow{3}{*}{$\mathrm{EW} / \mathrm{TL}$} & $\mathrm{M}+\mathrm{F}$ & 2.8 & 0.03 & 0.97 & 26 & $\operatorname{LogBW}=2.8 \log T L-1.52$ \\
\hline & & $\mathrm{M}$ & 2.77 & 0.03 & 0.96 & 15 & $\log B W=2.77 \log T L-1.52$ \\
\hline & & $\mathrm{F}$ & 2.87 & 0.02 & 0.98 & 11 & $\log B W=2.87 \log T L-1.70$ \\
\hline & \multirow{3}{*}{$\mathrm{BW} / \mathrm{SL}$} & $\mathrm{M}+\mathrm{F}$ & 2.71 & 0.08 & 0.97 & 26 & $\log B W=2.71 \log T L-1.10$ \\
\hline & & $\mathrm{M}$ & 2.65 & 0.09 & 0.98 & 15 & $\log B W=2.65 \log T L-1.05$ \\
\hline & & $\mathrm{F}$ & 2.83 & 0.06 & 0.97 & 11 & $\log B W=2.83 \log T L-1.22$ \\
\hline & \multirow{3}{*}{ EW/SL } & $\mathrm{M}+\mathrm{F}$ & 2.71 & 0.07 & 0.97 & 26 & $\log B W=2.71 \log T L-1.15$ \\
\hline & & $\mathrm{M}$ & 2.69 & 0.07 & 0.98 & 15 & $\operatorname{LogBW}=2.69 \log T L-1.15$ \\
\hline & & $\mathrm{F}$ & 2.79 & 0.06 & 0.96 & 11 & $\log B W=2.79 \log T L-1.22$ \\
\hline \multirow{12}{*}{ Lake Toho } & \multirow{3}{*}{$\mathrm{BW} / \mathrm{TL}$} & $\mathrm{M}+\mathrm{F}$ & 2.82 & 0.03 & 0.98 & 30 & $\log B W=2.82 \log T L-1.52$ \\
\hline & & $\mathrm{M}$ & 2.77 & 0.04 & 0.99 & 15 & $\log B W=2.77 \log T L-1.40$ \\
\hline & & $\mathrm{F}$ & 2.84 & 0.03 & 0.97 & 15 & $\log B W=2.84 \log T L-1.52$ \\
\hline & \multirow{3}{*}{$\mathrm{EW} / \mathrm{TL}$} & $\mathrm{M}+\mathrm{F}$ & 2.83 & 0.03 & 0.98 & 30 & $\log B W=2.83 \log T L-1.52$ \\
\hline & & $\mathrm{M}$ & 2.76 & 0.03 & 0.99 & 15 & $\log B W=2.76 \log T L-1.52$ \\
\hline & & $\mathrm{F}$ & 2.84 & 0.03 & 0.97 & 15 & $\log B W=2.84 \log T L-1.52$ \\
\hline & \multirow{3}{*}{ BW/SL } & $\mathrm{M}+\mathrm{F}$ & 2.58 & 0.11 & 0.98 & 30 & $\log B W=2.58 \log T L-0.96$ \\
\hline & & $\mathrm{M}$ & 2.62 & 0.1 & 0.98 & 15 & $\log B W=2.62 \log T L-1$ \\
\hline & & $\mathrm{F}$ & 2.52 & 0.13 & 0.98 & 15 & $\log B W=2.52 \log T L-0.89$ \\
\hline & \multirow{3}{*}{ EW/SL } & $\mathrm{M}+\mathrm{F}$ & 2.59 & 0.1 & 0.98 & 30 & $\log B W=2.59 \log T L-1$ \\
\hline & & $\mathrm{M}$ & 2.6 & 0.1 & 0.98 & 15 & $\log B W=2.6 \log T L-1$ \\
\hline & & $\mathrm{F}$ & 2.52 & 0.11 & 0.98 & 15 & $\log B W=2.52 \log T L+0.96$ \\
\hline \multirow{8}{*}{ Couffo river } & \multirow{3}{*}{$\mathrm{BW} / \mathrm{TL}$} & $\mathrm{M}+\mathrm{F}$ & 2.8 & 0.03 & 0.96 & 29 & $\log B W=2.8 \log T L-1.52$ \\
\hline & & $\mathrm{M}$ & 2.61 & 0.06 & 0.91 & 14 & $\log B W=2.61 \log T L-1.22$ \\
\hline & & $\mathrm{F}$ & 3.22 & 0.01 & 0.97 & 15 & $\log B W=3.22 \log T L-2$ \\
\hline & \multirow{3}{*}{ EW/TL } & $\mathrm{M}+\mathrm{F}$ & 2.89 & 0.02 & 0.93 & 29 & $\log B W=2.89 \log T L-1.7$ \\
\hline & & $\mathrm{M}$ & 2.38 & 0.1 & 0.86 & 14 & $\log B W=2.38 \log T L-1$ \\
\hline & & $\mathrm{F}$ & 3.17 & 0.01 & 0.9 & 15 & $\log B W=3.17 \log T L-2$ \\
\hline & \multirow{2}{*}{ BW/SL } & $\mathrm{M}+\mathrm{F}$ & 2.81 & 0.06 & 0.91 & 29 & $\log B W=2.81 \log T L-1.22$ \\
\hline & & $\mathrm{M}$ & 2.6 & 0.11 & 0.77 & 14 & $\operatorname{LogBW}=2.6 \log T L-0.96$ \\
\hline
\end{tabular}




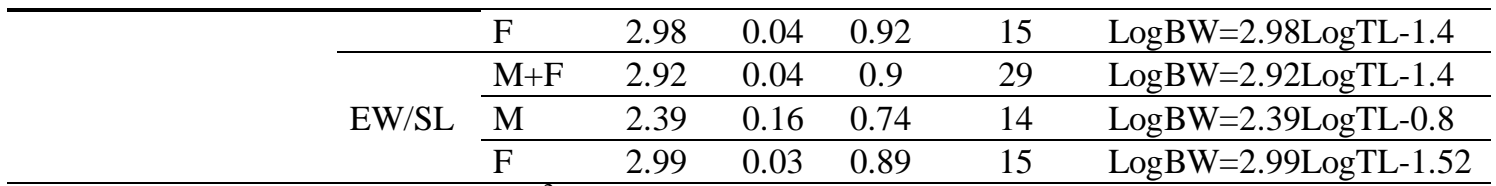

M: male; F: female; b: logarithmic slope; $\mathrm{R}^{2}$ : regression coefficient; BW: body weight; EW: eviscerated fish weight; TL: total length; SL: standard length.

\section{Discussion}

The tilapia Oreochromis niloticus can adapt to a large variation of ecological factors and colonizes extremely varied surrounding aquatic environments. Globally, in this study, whatever is the time of the day, the physicochemical parameters of the rearing water remained relatively stable $(p>0.05)$ throughout the experimental period. Variations in the water conductivity data reflect changes in the different ionic concentrations of water. The $\mathrm{pH}$ 's values are within within the limits recommended for this species (6.2 to 9) [27], [28]. [29] points out that Oreochromis niloticus can survive at $\mathrm{pH}$ values ranged between 8 and 11. [24] obtain an average $\mathrm{pH}$ equal to 6.93 for this tilapia species. The oxygen content influences the growth of Oreochromis niloticus. Indeed, a decrease in oxygen level involves an insufficient oxygen availability for the high energy needs of the fish, a slowing or interruption of food intake and therefore a reduction of the growth [30], [31]. Furthermore, compared to fish ponds, rearing tanks are less producers of algaes capable to provide oxygen sufficiently with the help of sunlight [32]. With regard to the water's temperature, the extremes recommended for Oreochromis niloticus breeding are between $16^{\circ} \mathrm{C}$ and $38^{\circ} \mathrm{C}$ with an optimum ranged from $28^{\circ} \mathrm{C}$ to $32^{\circ} \mathrm{C}$ [7]. Similarly, the favorable thermal interval for a better growth of Oreochromis niloticus is ranged from $24^{\circ} \mathrm{C}$ to $28^{\circ} \mathrm{C}$ [29], [33]. In the present study, the water temperature fluctuated between $27.38 \pm 0.37^{\circ} \mathrm{C}$ and $31.66 \pm 0.97^{\circ} \mathrm{C}$ while remaining within the limits recommended for the growth of this tilapia species. The water salinity varied from $0.29 \pm 0.04 \mathrm{mg} \mathrm{L}^{-1}$ to $0.39 \pm 0.6 \mathrm{mg} \mathrm{L}^{-1}$. According to [29], Oreochromis niloticus can tolerate salinities varying from 0.015 to $30 \%$. Moreover, Oreochromis niloticus is a stenohaline species whose best growth rates were observed in salinities ranged between 0 and $1 \mathrm{~g} \mathrm{~L}^{-1}$, although this species is able to tolerate salinities ranging from 0 to $7 \mathrm{~g} \mathrm{~L}^{-1}$ [34]. The values observed in this study do not constitute a limiting factor for its survival and growth because it is naturally adapted to freshwater. In the present study, the water was much more concentrated in suspended matters because the TDS was between 205 $\pm 76.33 \mathrm{ppm}$ and $280.63 \pm 9.29 \mathrm{ppm}$. However, following the assessment guide of the water TDS level [35], an appreciation "water of excellent quality" could be assigned to the water used in the experiment. The concentrations in chlorophyll « $\mathbf{a} »$

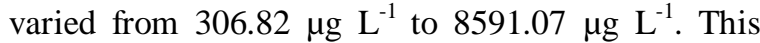
reflects the availability of a large quantity of microalgae for Oreochromis niloticus individuals used during the experiment. In Ghana, [36] reported concentrations of chlorophyll « $\mathbf{a} »$ ranged between $150 \mu \mathrm{g} \mathrm{L}^{-1}$ and $500 \mu \mathrm{g} \mathrm{L}^{-1}$ in intensive fish farming. These differences could be due to the fertilization and food residues encouraging an increase in the nutrients content in the tanks [37]. The species of zooplankton and phytoplankton counted in this study are those generally reported in the literature for freshwater tilapia farming [2], [38]-[41].

The growth of tilapia varies greatly from a species to another and from a population to another. This variation is also related to the strain used [42], food availability, populations demographic structure, catch selectivity and/or predation and the surface area of the waterway [7], [43]. The effect of geographical origin on the zootechnical parameters of tilapias is very poorly documented, contrary to production systems and rearing methods. [44] assessed the reproductive and growth characteristics of a highly domesticated stock of Oreochromis niloticus (from Côte d'Ivoire), two non-domesticated stocks (from Egypt and Sagana) and wild individuals (from lake Victoria). The combined effects of relative fertility, percentage of spawning females and successful incubation showed that Côte d'Ivoire's strain yielded eight times more fry per $\mathrm{kg}$ of female than the lake Victoria strain. Moreover, based on different hybrids Oreochromis niloticus X Oreochromis aureus, [45] showed that their geographical origin had a significant effect on the production traits including average initial weight, daily weight gain, survival rate, yield and sex ratio. Similarly, based on Menidia menidia, [46] demonstrated that the sex ratio sensitivity of this species is related to the geographical origin of the strains used. Furthermore, significant differences in total lipid content were observed in Perch (Perca fluviatilis) from the Rhine river and lake Geneva (1.21 and $1.48 \%$, respectively) [47]. The zootechnical closness (obtained in the dendogram) between lake Toho and Couffo river could be explained by the geographical proximity of these waterways and the similarity of some ecological factors. In this study, the weight gain did not differ significantly from a waterway to another $(24.65 \pm 12.86 \mathrm{~g}$ to $32.74 \pm 17.71 \mathrm{~g} ; \mathrm{p}>0.05)$. Depending on the stocking density of Oreochromis 
niloticus, [48] obtain the weight gains ranging from $40.24 \pm 7.64 \mathrm{~g}$ to $54.03 \pm 7.76 \mathrm{~g}$ (for 10 individuals $\mathrm{m}^{-2}$ ) and $36.65 \pm 5.73 \mathrm{~g}$ to $46.11 \pm 5.87 \mathrm{~g}$ (for 13 individuals $\mathrm{m}^{-2}$ ) respectively. In Burkina Faso, [3] record the weight gains of $25.79 \pm 1.54 \mathrm{~g}$ in fish hole and $33.43 \pm 2.47 \mathrm{~g}$ in a cage for this tilapia species. The value of the weight gain depends on the physiological state, the stocking density effect, the strain and the origin of the fish [49]. The average weight gain didn't vary statistically according to the sex $(\mathrm{p}>0.05)$. However, it was higher in males than females $(5.22 \pm 3.79 \mathrm{~g}$ vs $4.57 \pm 3.28 \mathrm{~g})$. In Oreochromis niloticus rearing ponds, [50] observed that the highest average weight gains are obtained in the batches that containing $95 \%$ of males and more. In "Côte d'Ivoire", [2] found an average weight gain of $11.04 \pm 0.05 \mathrm{~g}$ in fish farming. This parameter is influenced by the stocking effect and the initial weight of the fish used during experiments. Depending on the strain used, the feeding and rearing conditions, tilapia may deliver an individual daily growth of 2 to $4 \mathrm{~g} \mathrm{day}^{-1}$ [7]. In this study, the daily weight gain did not vary significantly from a population to another. The values gotten are similar to those reported in the literature. Indeed, [51] observed an individual average growth of $2.81 \pm 0.07$ $\mathrm{g} \mathrm{day}^{-1}$ for Bouaké strain, $2.50 \pm 0.05 \mathrm{~g} \mathrm{day}^{-1}$ for Daloa strain and $2.50 \pm 0.10 \mathrm{~g} \mathrm{day}^{-1}$ for Burkina Faso strain. In brackish water fish farming of Oreochromis niloticus, [24] reported an average daily gain of 0.75 $\mathrm{g} \mathrm{day}^{-1}$. In Burkina Faso, [3] recorded the daily weight gains of $0.67 \pm 0.04 \mathrm{~g} \mathrm{day}^{-1}$ and $0.88 \pm 0.07 \mathrm{~g}$ day $^{-1}$ respectively in cage and fish hole. Male individuals showed the ponderal and linear specific growth rates higher than those of females. These results are in agreement with those of [49], [52], [53] who show that the male tilapias have a better growth performance compared to females. After 91 rearing days in fertilized tanks, [53] record specific growth rates equal to $2.77 \pm 0.09 \%$ day $^{-1}$ and $2.38 \pm 0.05 \%$ day $^{-1}$ respectively for Oreochromis niloticus' males and females. In cage and hapa aquaculture, [49] found the respective specific growth rates of $1.22 \pm$ $0.03 \%$ day $^{-1}$ and $0.80 \pm 0.04 \%$ day $^{-1}$. In brackish water fish farming of Oreochromis niloticus, [24] reported a specific growth rate equal to $1.49 \%$ day $^{-1}$. By enhancing the production of natural food in fish ponds, the fish production can increase and its costs can reduce. [54] showed that periphyton plays a central role in the growth of Oreochromis niloticus. Indeed, Nile Tilapia juveniles fed by the lower protein diets with periphyton performed better $(p<0.05)$ than those fed by the $25 \%$ crude protein control diet with no periphyton $(3.36 \pm 0.04$ and 3.39 $\pm 0.05 \%$ day $^{-1}$ vs $3.06 \pm 0.05 \%$ day $^{-1}$ ). In the present study, the availability of several plankton species encouraged the best growth rates recorded. The linear specific growth rates recorded in the present study are similar to those reported for Oreochromis niloticus by [24] in Ivorian lagoons $\left(0.48 \%\right.$ day $\left.^{-1}\right)$. The nutritive quotients recorded in this study are higher than those observed by [48], [55] in fish tanks and ponds to "Côte d'Ivoire". Indeed, depending on the alimentary treatment, fry of Oreochromis niloticus subjected to a diet without fish meal have shown the nutritive quotients of 0.98 and 1.3 in the rearing tanks [55]. Oreochromis niloticus fingerlings reared under the stocking densities of 10 individuals $\mathrm{m}^{-2}$ and 13 individuals $\mathrm{m}^{-2}$ showed the nutritive quotients ranging from 1.13 to 1.87 [48]. In Congo, [56] relate the respective nutritive quotients of $10.2 \pm 0.2$ and $12.2 \pm 6.3$ in Oreochromis niloticus ponds and floating cage. In addition, [3] observe the values of 2.72, 0.97 and 7.37 for this parameter in cage and fish hole to Burkina Faso. Otherwise, in an isolated strain of the tilapia Sarotherodon melanotheron, [57] recorded the high nutritive quotients equal to $17.66 \pm$ $0.54,6.13 \pm 2.23$ and $8.28 \pm 1.75$ in tank, ponds and cage respectively. These differences in nutritive quotients could be due to the quality of the food used during these various experiments. Moreover, the smaller the nutritive quotient is, the better the food is and the better the fish grow ([25]). The condition factor is an important parameter of the fish relative stoutness expression. It is useful for understanding the impacts of variations in environmental conditions on species and is also used as a measure of the physiological development stage of fish. Globally, the condition factor computed for Oreochromis niloticus were ranged from $3.67 \pm 0.94$ to $5.25 \pm$ 1.51, which indicated a good health condition during the experiment. The similar condition factors have been obtained by [49] in floating cage $(3.83 \pm 0.09)$ and hapa $(3.80 \pm 0.05)$. Similarly, [58] reports the conditions factor equal to $3.54 \pm 0.02$ and $3.66 \pm 0.02$ in Ghana for Oreochromis niloticus 's individuals under selective breeding. At lake Toho, [59]recorded the monthly variation of condition factor ranged from 1 to 2 in Oreochromis niloticus. With Oreochromis niloticus's fingerlings fed on different levels of maltose, the condition factors were $1.64,1.77,1.74$, 1.72 and 1.79 [60]. The survival rates recorded in the present experiment are satisfactory and similar to those reported for Oreochromis niloticus in the literature: $65.02 \pm 4.71 \%$ [2], $79.34 \pm 6.55 \%$ to 94.2 $\pm 2.48 \%$ [48], 52.85\% [24], $80 \%$ and $95-100 \%$ [61], 97.5 and 98.2 [53]. [51] indicate the survival rate equal to $90.20(0) \%$ for Bouaké strain, 94.24(3.09)\% for Daloa strain and 89.69(1.55)\% for Burkina Faso strain. As for the relative growth coefficient $b$, when it is equal to 3, isometric pattern of growth occurs, but when $b$ is not equal to 3 , allometric pattern of growth occurs, which may be positive if $>3$ or negative if $<3$ [62]. In our study, b ranged from 2.38 
to 3.22. The majority of the individuals has the value of $b<3$, so they grow more in length than weight. [2] got the allometric coefficients equal to $2.84 \pm 0.14$ and $2.79 \pm 0.23$ respectively in fish farming and fishrice integrated system of Oreochromis niloticus. Furthermore, according to [60], the values of the regression coefficient for fish fed on different maltose levels $(0.0 \%, 20 \%, 25 \%, 30 \%$ and $35 \%)$ was respectively $0.82,0.87,0.93,0.82$ and 0.90 . For this species, [63] recorded the values of $b$ ranged from 2.169 and 3.441 in the hydrographic basin of Comoé (Burkina Faso). At the end of the experiment, most of individuals were at the $\mathrm{IV}^{\text {th }}$ sexual maturity stage $(42.86 \%-93.33 \%)$. This results from the fact that the two sexes were separated during the experiment. This is in accordance with the finding of [52] who concluded that sexual maturation could be involved in the expression of sexual growth dimorphism. Moreover, the gonado-somatic ratio (RGS) and the gonado-somatic index (GSI) permit to characterize the sexual maturation of Oreochromis niloticus individuals. Variations in the RGS and GSI show that the ovaries weight is higher than the one of testicles so that the reproductive parameters were higher in females than males. This finding corroborates with the observations of [52]. However, [64] observed that the final GSI of females and males $(2.57 \%$ to $3.22 \%$ vs $0.64 \%$ to $0.81 \%$ ) were not affected by the feed type $(\mathrm{p}>0.05)$.

Overall, Oreochromis niloticus individuals from Ouémé river performed more than those of lake Toho and Couffo river. The majority of individuals indicated an allometric growth, which is less desirable for fish farming. Two populations are distinguished: the group that is only constituted of Ouémé river and the one including lake Toho with Couffo river. The implementation of a selective breeding program of these local populations of Oreochromis niloticus will improve their zootechnical performances.

\section{Acknowledgements}

T. Olivier Amoussou benefited from the International Foundation for Science (Stockholm, Sweden), the European Union through the HAAGRIM project (INTRA-ACP ACADEMIC MOBILITY SCHEME) and the Government of France through SCAC "Service de Coopération et d'Action Culturelle" of the France embassy in Cotonou, Benin. The authors are grateful to the UEMOA "Union Economique et Monétaire Ouest Africaine" for its financial support through the PAES/Tilapia project.

\section{References:}

[1] FAO. 2014. The state of world fisheries and aquaculture. FAO. Rome, Italy.

[2] Avit, J.-B.L.F., Bony, K.Y., Kouassi, N.C., Konan, K.F.
Assemian, O. and . Allouko, J. 2012. Conditions écologiques de production de fingerlings de Oreochromis niloticus (Linné, 1758) en association avec le riz WITA 12 en étang. J. Appl. Biosci., 59, 42714285 .

[3] Amoussou, T.O., Youssao, A.K.I. and Toguyeni, A 2014. Improving aquaculture production in the Kou valley, Burkina Faso. Agric. Innov. Sustain. Dev., 4(3), 187-194.

[4] Ouattara, N., 2009. Adaptation écophysiologique des branchies à l'hypersalinité chez le tilapia Sarotherodon melanotheron. Université Montpellier 2.

[5] Tanoh Kamelan, M., Berté, S., Zi, G.K.N., Bamba, M. Goore, G.B. and Essetchi, P. 2013. Peuplement ichtyologique du complexe Brimé-Méné-Nounoua, Côte d'Ivoire (Afrique de l'Ouest). Int. J. Biol. Chem. Sci., 7(6), 2248-2263.

[6] Tembeni, J.M., Micha, J.C., Mbomba, B.N.S. Vandewalle, P. and Mbadu, V.Z. 2014. Biologie de la reproduction d'un poisson chat Africain Euchilichthys guentheri (Schilthuis, 1891) (Mochokidae, Siluriformes) au Pool Malebo, Fleuve Congo (République Démocratique du Congo). Tropicultura, 32(3), 129-137.

[7] Lazard, J. 2009. La pisciculture des tilapias. Cah. Agric., 18(2-3), 393-401.

[8] Lazard, J. 2014. La diversité des piscicultures mondiales illustrée par les cas de la Chine et du Nigeria. Cah. Agric., 23(1), 24-33.

[9] Abban, E.K. and Agyakwa, S. 2004. Socio-economic importance of Tilapia in West Africa. In: Biodiversity, management and utilisation of West African fishes. WorldFish Center Conference Proceedings, 1-2.

[10] FAO. 2012. The state of world fisheries and aquaculture. FAO. Rome, Italy.

[11] Trewavas, E. 1984. Tilapiine Fishes of the Genera Sarotherodon, Oreochromis, and Danakilia. London, UK: British Museum Natural History.

[12] Paugy, D., Lévêque, C. and Teugels, G.G. 2004. Faune des poissons d'eau douce et saumâtre d'Afrique de l'Ouest. ${ }^{\text {nd }}$ ed. Paris, France: Faune et flore tropicales.

[13] Li, S.F., He, X.J., Hu, G.C., Cai, W.Q., Deng, X.W. and Zhou, P.Y. 2006 .Improving growth performance and caudal fin stripe pattern in selected F6-F8 generations of GIFT Nile tilapia (Oreochromis niloticus L.) using mass selection. Aquac. Res., 37(2), 1165-1171.

[14] Toguyeni, A., Fauconneau, B., Melard, C., Fostier, A., Lazard, J., Baras, E., Kuhn, E., van der Geyten, S. and Baroiller, J.-F. 2009. Sexual dimorphism in two pure cichlid species, Oreochromis niloticus niloticus (Linnaeus, 1758) and Sarotherodon melanotheron melanotheron Ruppel 1852, and their intergeneric hybrids. African J. Aquat. Sci., 34(1), 69-75.

[15] FAO. 2010. The state of world fisheries and aquaculture. FAO, Rome, Italy.

[16] Ansah, Y.B., Frimpong, E.A. and Hallerman, E.M. 2014 Genetically-improved tilapia strains in Africa: Potential benefits and negative impacts. Sustainability, 6(6), 36973721.

[17] Adebo, G.M. and Alfred, S.D.Y. 2008. Economic analysis of contribution of tilapia production and marketing to gender empowerment in Ondo and Ekiti states, Nigeria. In $8^{\text {th }}$ International Symposium on Tilapia in Aquaculture, 657-664.

[18] ADB. 2005. An impact evaluation of the development of genetically improved farmed tilapia. Mandaluyong, Philippines: Asian Development Bank.

[19] Rognon X. and Guyomard, R. 2003. Large extent of mitochondrial DNA transfer from Oreochromis aureus to O. niloticus in West Africa. Mol. Ecol., 12(2), 435-445.

[20] Tatsadjieu, N.L., Maïworé, J., Hadjia, M.B., Loiseau, G., Montet, D. and Mbofung, C.M.F. 2010. Study of the microbial diversity of Oreochromis niloticus of three 
lakes of Cameroon by PCR-DGGE: Application to the determination of the geographical origin. Food Control, 21(5), 673-678.

[21] Mian, G.F., Godoy, D.T., Leal, C.A.G., Yuhara, T.Y., Costa, G.M. and Figueiredo, H.C.P. 2009. Aspects of the natural history and virulence of S. agalactiae infection in Nile tilapia. Vet. Microbiol., 136(1-2), 180-183.

[22] Bigarré, L., Cabon, J., Baud, M., Heimann, M., Body, A., Lieffrig, F. and Castric, J. 2009. Outbreak of betanodavirus infection in tilapia, Oreochromis niloticus (L.), in fresh water. J. Fish Dis., 32(8), 667-673.

[23] Cohen, T., Hee, S.S.Q. and Ambrose, R.F. 2001. Trace metals in fish and invertebrates of three California Coastal Wetlands. Mar. Pollut. Bull., 42(3), 224-232.

[24] Gbaï, M., Yao, K. and Atse, Y.N.A.B.C. 2014. Etude comparée de la croissance et de la survie des hybrides Sarotherodon melanotheron $\mathrm{x}$ Oreochromis niloticus, de $O$. niloticus et des tilapias autochtones des lagunes ivoiriennes ( $S$. melanotheron et Tilapia guineensis). Livest. Res. Rural Dev., 26(1), 1-8.

[25] Amoussou, T.O., Toguyeni, A., Imorou Toko, I., Chikou, A., Bravo, M. and Youssao Abdou Karim, I. 2017. Evaluation of zootechnical and reproductive parameters of wild populations of Sarotherodon melanotheron Rüppell, 1852 of Southern Benin raised in captivity. Int. J. Fish. Aquac., 9(1), 1-13.

[26] Plisnier, P.D., Micha, J.C. and Frank V. 1988. Biologie et exploitation des poissons du Lac Ihema (Bassin Akagera, Rwanda). Namur, Belgique: Presses universitaires de Namur.

[27] De Kinkelin, P., Michel, C. and Ghittino P. 1985. Précis de pathologie des poissons. Lavoisier. Paris, france: Office Internationale des Epizooties-INRA TEC \& DOC,.

[28] Kanangire, C.K. 2001. Effets de l'alimentation des poissons avec Azolla sur la production d'un écosystème agro-piscicole en zones marécageuses au Rwanda. Facultés Universitaires Notre-Dame de la Paix.

[29] Lacroix, E. 2004. Pisciculture en zone tropicale. Hamburg Allemagne,.

[30] Mélard, C. 2014. Base biologique de l'aquaculture: éléments de génétique II. Note de cours à l'intention des étudiants de Master Complémentaire en Aquaculture. CEFRA, Université de Liège, Tihange, Belgique, p. 57.

[31] Mélard, C. 2014. Base biologique de l'aquaculture: éléments de génétique III. Note de cours à l'intention des étudiants de Master Complémentaire en Aquaculture. CEFRA, Université de Liège, Tihange, Belgique, p. 63.

[32] Van Eer, A., Van Schie, T. and Hilbrands, A. 2004. La pisciculture à petite échelle en eau douce. Wageningen, Netherlands: Fondation Agromisa.

[33] Beveridge, M.C.M. and McAndrew, B.J. 2010. Tilapias: Biology and Exploitation. London, UK: Kluwer Academic.

[34] Likongwe, J.S., Stecko, T.D., Stauffer, J.R. and Carline, R.F. 1996 .Combined effects of water temperature and salinity on growth and feed utilization of juvenile Nile tilapia Oreochromis niloticus (Linneaus). Aquaculture, 146(1-2), 37-46.

[35] WHO. 1996. Total dissolved solids in Drinking-water background document for development of WHO Guidelines for Drinking-water Quality. Geneva, Switzerland: World Health Organization.

[36] Frimpong, E., Ansah, Y., Amisah, S., Adjei-Boateng, D., Agbo, N. and Egna, H. 2014. Effects of two environmental best management practices on pond water and effluent quality and growth of Nile Tilapia, Oreochromis niloticus. Sustainability, 6(2), 652-675.

[37] Agadjihouede, H., Bonou, C.A., Montchowui, E., Chikou, A. and Laleye, P. 2011. Capacité de développement de trois espèces zooplanctoniques d'intérêts aquacoles (Brachionus calyciflorus, Moina micrura et Thermocyclops sp.) élevées en condition monospécifique en aquariums avec la fiente de volaille. Tropicultura, 29(4), 231-237.

[38] Dabbadie, L.M. 1996. Etude de la viabilité d'une pisciculture rurale à faible niveau d'intrant dans le centre-ouest de la Côte d'Ivoire: Approche du réseau trophique. Université Paris 6.

[39] Isumbisho Mwapu, P. 2006. Ecologie du Zooplancton du Lac Kivu (Afrique de l'Est ). Facultés Universitaires Notre-Dame de la Paix.

[40] Trintignac, P., Bouin, N., Kerleo, V. and Le Berre, M. 2013. Guide de bonnes pratiques pour la gestion piscicole des etangs. La Ferrière (France): SMIDAP.

[41] Houssou, A.M., Agadjihouédé, H., Montchowui, E., Bonou, C.A. and Lalèyè, P. 2015. Structure and seasonal dynamics of phytoplankton and zooplankton in Lake Azili , small Lake of the pond of River Ouémé, Benin. Int. J. Aquat. Biol., 3(3), 161-171.

[42] Dan N.C. and Little, D.C. 2000. Overwintering performance of Nile tilapia Oreochromis niloticus (L.) broodfish and seed at ambient temperatures in northern Vietnam. Aquac. Res., 31, 485-493.

[43] Ouattara, N.I., Iftime, A. and Mester, L.E. 2009. Age et croissance de deux espèces de Cichlidae (pisces): Oreochromis niloticus (Linnaeus, 1758 ) et Sarotherodon melanotheron Rüppell, 1852 du lac de barrage d'Ayamé (Côte d'Ivoire, Afrique de l'Ouest). Trav. du Muséum Natl. d'Histoire Nat. "Grigore Antipa», LII, 313-324.

[44] Osure G.O. and Phelps, R.P. 2006. Evaluation of reproductive performance and early growth of four strains of Nile tilapia (Oreochromis niloticus, L) with different histories of domestication. Aquaculture, 253(14), 485-494.

[45] Hulata, G., Wohlfarth, G.W., Karplus, I., Schroeder, G.L., Harpaz, S., Halevy, A., Rothbard, S., Cohen, S., Israel, I. \& Kavessa, M. 1993. Evaluation of Oreochromis niloticus X $O$. aureus hybrid progeny of different geographical isolates, reared under varying management regimes. Aquaculture, 115(3-4), 253-271.

[46] Conover D.O. and Kynard, B.E. 1981. Environmental sex determination: Interaction of temperature and genotype in a fish. Science., 213(4507), 577-579.

[47] Mairesse, G., Thomas, M., Gardeur, J.N. and BrunBellut, J. 2006. Effects of geographic source, rearing system, and season on the nutritional quality of wild and farmed Perca fluviatilis. Lipids, 41(3), 221-229.

[48] Bamba, Y., Ouattara, A., Da Costa, K.S. and Gourene, G. 2008. Production de Oreochromis niloticus avec des aliments à base de sous-produits agricoles. Sci. Nat., 5(1), 89-99.

[49] Mensah, E.T.D., Klenam, F., Attipoe, Y. and Atsakpo, K. 2014. Comparative growth study of Oreochromis niloticus and Sarotherodon galilaeus under two different culture regimes (Hapa-In-Pond and cage systems). Int. J. Fish. Aquat. Stud., 1(5), 53-59.

[50] Mair, G.C. and Van Dam, A.A. 1996. Effets de sexe ratio à l'empoissonnement sur la croissance et le recrutement dans des étangs d'élevage de tilapias du Nil (Oreochromis niloticus L.). In ICLARM Conference Proceedings, 109-117.

[51] Morissens, P., Rognon, X. and Dembele, I. 1996 Comparison of growth performance and electrophoretic characteristics of three strains of Oreochromis niloticus present in Côte-d'Ivoire; In ICLARM Conference Proceedings, 400-407.

[52] Toguyeni, A., Fauconncau, B., Fostier, A., Abucay, J., Mair, G. and Baroiller, J.F. 2002. Influence of sexual phenotype and genotype, and sex ratio on growth performances in tilapia, Oreochromis niloticus. Aquaculture, 207, 249-261.

[53] Owusu-Frimpong, M., Attipoe, F.Y.K. and Padi, J.N. 2005. Comparison of some traits of economic 
importance in tilapias (Oreochromis niloticus and Sarotherodon galilaeus) with particular reference to their culture in Ghana. Naga WorldFish Cent. Q., 28(3 \& 4), 33-36.

[54] Sakr, E.M., Shalaby, S.M., Wassef, E.A., El-Sayed, A.F.M. and Moneim, A.I.A. 2015. Evaluation of periphyton as a food source for Nile Tilapia (Oreochromis niloticus) juveniles fed reduced protein levels in cages. J. Appl. Aquac., 27(1), 50-60.

[55] Bamba, Y., Ouattara, A. and Gourène, G. 2007. Production d'alevins de tilapia (Oreochromis niloticus L., 1758) nourris avec des sous-produits agricoles, sans adjonction de farine de poisson. Agron. Africaine, 19(2), 211-221.

[56] Ngokaka, C., Akouango, F., Mamonékéné, V. and Mbouala, G.K. 2010. Comparison of the zoo technical performances of Oreochromis niloticus between the traditional and the new floating cages breeding methods. J. Anim. Plant Sci., 7(1), 760-766.

[57] Ouattara, N.I., N'Douba, V., Kone, T., Snoeks, J. and Philippart, J.C. 2005. Performances de croissance d'une souche isolée du tilapia estuarien Sarotherodon melanotheron (Perciformes, Cichlidae) en bassins en béton, en étangs en terre et en cages flottantes. Ann. l'Université Mar. Ngouabi, 6(1), 113-119.
Attipoe, F.Y.K. 2006. Breeding and selection for faster growth strains of the Nile Tilapia, Oreochromis niloticus in Ghana. University of Cape Coast.

[59] Ahouansou-Montcho, S. and Laleye, P.A. 2008. Some aspects of biology of Oreochromis niloticus L. (Perciformes: Cichlidae ) recently introduced in Lake Toho (Benin, West Africa). Int. J. Biol. Chem. Sci., 2(1), 114-122.

[60] Ighwela, K.A., Ahmed, A.B. and Abol-Munafi, A.B. 2011. Condition factor as an indicator of growth and feeding intensity of Nile Tilapia fingerlings (Oreochromis niloticus) feed on different levels of maltose. Am. J. Agric. Environ. Sci., 11(4), 559-563.

[61] Beaven, U. and Muposhi, V. 2012. Aspects of a monosex population of Oreochromis niloticus fingerlings produced using 17- $\alpha$ methyl testosterone hormone. $J$. Aquac. Res. Dev., 3(3), 1-5.

[62] Froese, R. 2006. Cube law, condition factor, and weightlength relationship: History, meta-analysis and recommendations. J. Appl. Ichtyology, 22(4), 241-253.

[63] Sirima, O., Toguyeni, A. and Kabore-Zoungrana, C. 2009. Faune piscicole du bassin de la Comoé et paramètres de croissance de quelques espèces d'intérêt économique. Int. J. Biol. Chem. Sci., 3(1), 95-106.

[64] Bhujel, R.C., Yakupitiyage, A., Turner, W.A. and Little, D.C. 2001. Selection of a commercial feed for Nile tilapia (Oreochromis niloticus) broodfish breeding in a hapa-in-pond system. Aquaculture, 194(3-4), 303-314. 